\title{
Electric utility on the basis of renewable energy sources at realisation of "Smart city" concept
}

\author{
Svetlana Shilkina* \\ Moscow State University of Civil Engineering, Yaroslavskoe shosse, 26, Moscow, 129337, Russia
}

\begin{abstract}
Realisation of "Smart city" concept is connected with introduction of activities as to increase in energy efficiency and resource saving in the area of electric utility industry, including for the account of applying renewable energy sources (RES). Introduction of concept elements is economically justified not only in big megapolises, but in minor residential areas, as well. Notwithstanding the growth in power production with the employment of sun and wind technologies, the share of RES-based power generating plants in Russia, remains inconsiderable and amounts to approximately $0.1 \%$ of the total registered output of country's power sources. Development of this perspective sphere is mainly carried out in those Russian regions where diesel fuel is used at very high potential capacities of the sun and wind power. Projects as to RES development in Russia are economically substantiated for isolated power-engineering systems, their introduction allows to cut consumption rate of expensive diesel fuel which is environmentally unfriendly. The estimates as referred herein, evidence a necessity to substitute elements of power-generating equipment of diesel-powered plants with solar-power farms. Development of renewable energy-generating industry in the country must be facilitated, by accelerated introduction of this resource in the regions with autonomous power-supply, where RES provides a fairly good economic effect.
\end{abstract}

\begin{abstract}
"Smart city" concept has strongly turned from an ephemeral notion of technologies of the future into casual vital activities, due to which management of city's internal processes is simplified and living conditions of population are increased. The mission of "Smart city" programmes is to increase the living conditions in the megapolis, to create comfortable environment for work and leisure. So far, a single list of parameters which implementation would definitely characterise the city as "smart" is not available. Whereas, each researcher agrees that as an integral part of evaluations and ratings of the smartest cities, on the first place introduction of energy efficiency and resource saving in the area of electric utility industry, including for the account of applying renewable energy sources (RES), is always specified. As a rule, concepts are developed for major megapolises; however, within modern environment, realisation of separate components of "Smart city" concept is justified economically and socially in minor communities, as well. This article is purposed at evidencing this thesis with the case study of RES introduction into power supply of minor settlements in isolated power-supply systems.
\end{abstract}

\footnotetext{
*Corresponding author: Shilkina@bk.ru
} 
Recently, according to International Energy Agency (further - IEA), for the second time in a row, electric utility industry is the leader in terms of investments into power engineering; this reflects the ongoing trend for global economy electrification and it is supported by significant investments into grids and renewable energy sources [1]. Investment dynamics into the principle oil \& gas sector as well into electric utility industry vividly illustrates this trend (figure 1).

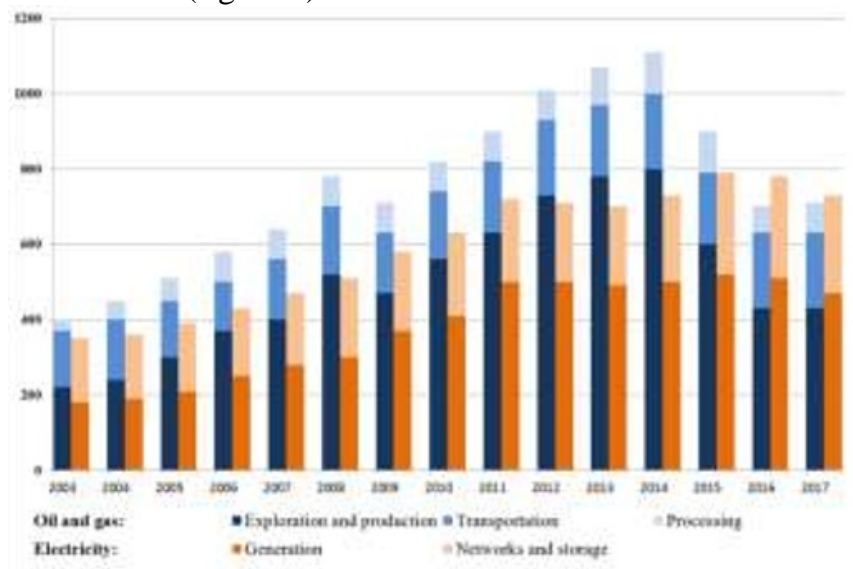

Fig. 1. Investment dynamics into the oil \& gas sector as well into electric utility industry, bln. USD

Due to a unique capacity of electric power to generate practically any other type of energy, electric utility industry is an integral part of all the spheres of human activities [2] (figure 2).

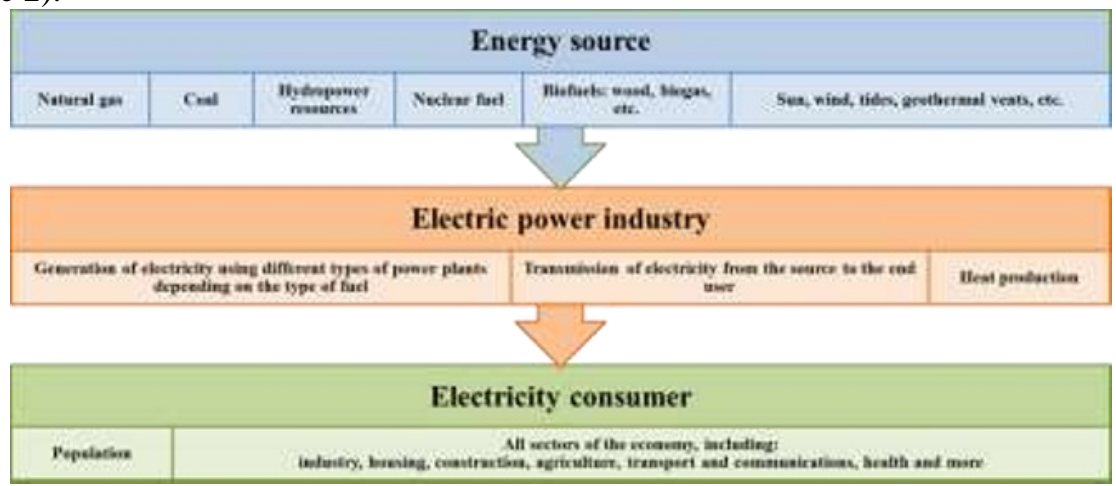

Fig. 2. Interconnection of electric utility industry with economy sectors

Four main types of power generating plants for electric energy production are distinguished:

- $\quad$ thermal power plants;

- $\quad$ hydroelectric power plants;

- $\quad$ nuclear power plants;

- $\quad$ renewable energy source based power plants.

Cut of costs for equipment manufacture continues effecting considerably the investment trends, prices and competition between various power industry sectors.

Development of RES-based electric utility industry globally. Outcomes and perspectives.

In 2017, record-breaking 157 gigawatt (GW) of RES were commissioned worldwide, which is considerably higher than $143 \mathrm{GW}$ of commissioned RES in 2016 and is far ahead of 70 
GW of net capacities for production of electric energy based on fossil fuels which were added in 2016 [3]. As a result, the share of electric power being generated on RES basis, increased from $11 \%$ in 2016 to $12.1 \%$ in 2017 , which approximately corresponds to 1.8 gigatons of prevented carbon dioxide emissions. Whereas, for the third year in a row, investments into RES in developing markets exceed those into the same sector of developed markets (figure 3).

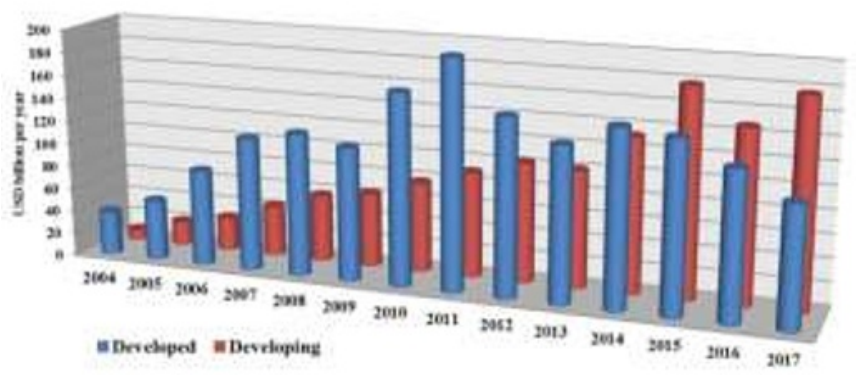

Fig. 3. Dynamics of investments into RES in developed and developing markets, USD, bln.

It is natural, that priority development of RES is a consequence of increase in global investments: in 2017 they increased by $2 \%$ up to $\$ 279,8$ bln., a considerable part of investments is donations of a number of countries. As a result, upward trends of aggregate investments into RES remained at place. Since 2010, investments reached a value of $\$ 2.2$ trillion and since $2004-\$ 2.9$ trillion. At the same time, it is worth mentioning that growth of capital expenses recently has taken place within conditions of ongoing surge in the price of equipment for wind energy generation (by WPPs - wind power plants) and solar energy generation (by SPP - solar power plants) [4] (figure 4). For example, specific expenses for solar photovoltaic projects, which count for $8 \%$ from the total volume of investments into power industry worldwide, have fallen down in average by almost $15 \%$ due to lower prices for modules and a "shift" in implementation of those projects to "cheaper" regions. These trends are represented on the layout demonstrating dynamics of variation of averaged price for SPP installation in a number of countries and regions [1] (figure 5).

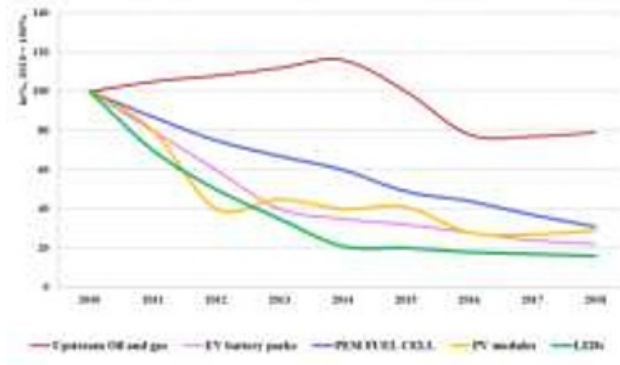

Fig. 4. Variation of price of the equipment generating various energy types, in $\%$ to 2008

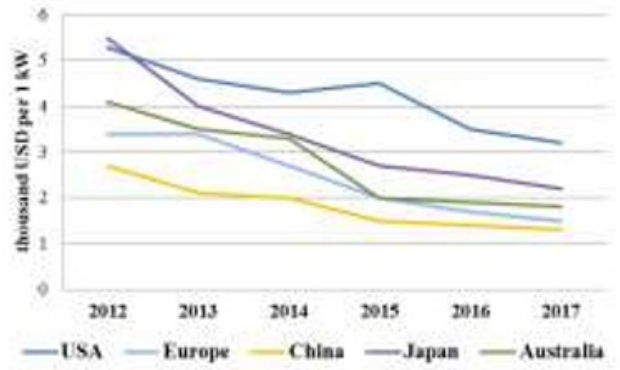

Fig. 5. Dynamics of price variation for SPP installation in a number of countries, USD thous. per $1 \mathrm{~kW}$

China has become the leader in terms of volume of investments into renewable energy sources in 2017; its share amounted to USD 126.6 bln. which is the highest figure ever and constitutes at least $45 \%$ of the global volume [3] (figure 6). 
In 2017, a real "solar glut" took place in China; the commissioned established capacity amounted to $53 \mathrm{GW}$ by SPP (which exceeds the global market in 2014), and the aggregate "solar" investments amounted to USD 60 billion [1] (figure 7).

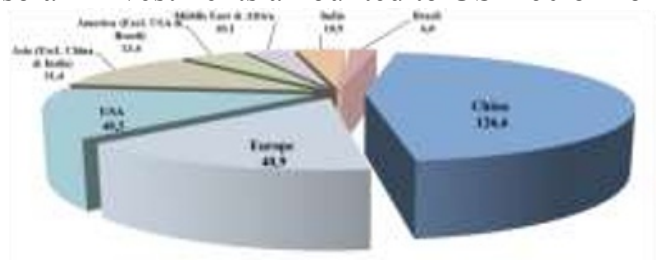

Fig. 6. Investments into RES by countries and regions in 2017, bln. USD

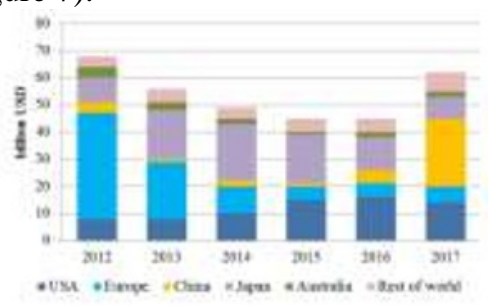

Fig. 7. Investment dynamics into SPP, bln. USD

As a result, according to the international non-profit Association REN21 (further herein: REN21) [5], in the end of 2017 the total capacity of RES-based power plants as installed worldwide (excluding hydro electrical power sector) exceeded $1000 \mathrm{GW}$ (table 1).

Table 1. Capacity of installed power plants based on renewable energy sources, by some countries and regions as of $2017, \mathrm{GW}$.

\begin{tabular}{|c|c|c|c|c|c|c|c|c|c|}
\hline & $\frac{\pi}{0}$ & 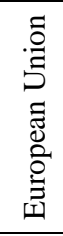 & $\stackrel{\widetilde{a}}{\Xi}$ & 芯 & $\widehat{\overparen{\Xi}}$ & 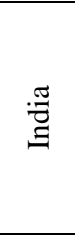 & 跑 & 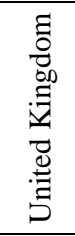 & $\begin{array}{l}\bar{\pi} \\
\frac{\pi}{0} \\
\frac{0}{0} \\
\vdots \\
3\end{array}$ \\
\hline BIO-power & 40 & 40 & 14,9 & 16,7 & 8 & 9,5 & 3,6 & 6 & 122 \\
\hline Geothermal power & 0,1 & 0,8 & $\sim 0$ & 2,5 & $\sim 0$ & 0 & 0,5 & 0 & 12,8 \\
\hline Hydropower & 507 & 124 & 313 & 80 & 5,6 & 4,5 & 23 & 1,9 & 1114 \\
\hline Ocean power & $\sim 0$ & 0,2 & $\sim 0$ & $\sim 0$ & 0 & 0 & 0 & $\sim 0$ & 0,5 \\
\hline Solar PV & 152 & 108 & 131 & 51 & 42 & 18,3 & 49 & 12,7 & 402 \\
\hline $\begin{array}{l}\text { Concentrating solar thermal } \\
\text { power (CSP) }\end{array}$ & 0,5 & 2,3 & $\sim 0$ & 1,7 & $\sim 0$ & 0,2 & 0 & 0 & 4,9 \\
\hline Wind power & 236 & 169 & 188 & 89 & 56 & 33 & 3,4 & 18,9 & 539 \\
\hline $\begin{array}{l}\text { Total renewable power } \\
\text { capacity (including } \\
\text { hydropower) }\end{array}$ & 936 & 443 & 647 & 241 & 112 & 106 & 79 & 39 & 2195 \\
\hline $\begin{array}{l}\text { Total renewable power } \\
\text { capacity (not including } \\
\text { hydropower) }\end{array}$ & 429 & 320 & 334 & 161 & 107 & 61 & 57 & 38 & 1081 \\
\hline
\end{tabular}

In many countries of the world, state projects on development of RES-based electric utility industry are approved. Some countries have set a goal of switching to $100 \%$ generation of electric power with the use of RES by 2050. However, the great majority of those countries do not possess developed energy-intensive industry. Among them: Afghanistan, Bangladesh, Cambodia, Colombia, Democratic Republic of the Congo, Costa Rica, Dominican Republic and other minor developing countries. Whereas, industrially developed countries set less ambitious goals ahead [5] (table 2):

Table 2. RES share in some countries presently and perspectively.

\begin{tabular}{|c|c|c|}
\hline Country & RES share presently & $\begin{array}{c}\text { Purposes under the strategy of RES } \\
\text { development }\end{array}$ \\
\hline Belgium & $16 \%$ & $20,9 \%$ at 2020 \\
\hline Bulgaria & $19 \%$ & $20,6 \%$ at 2020 \\
\hline Chile & $16 \%$ & $20 \%$ at 2020 \\
\hline Cyprus & $8,6 \%$ & $16 \%$ at 2020 \\
\hline
\end{tabular}




\begin{tabular}{lcc}
\hline Germany & $32 \%$ & $40-45 \%$ at 2025 \\
Greece & $24 \%$ & $40 \%$ at 2020 \\
Republic of Korea & & $7 \%$ at 2020 \\
Poland & $13 \%$ & $19,3 \%$ at 2020 \\
Spain & $37 \%$ & $38,1 \%$ at 2020 \\
Turkey & & $30 \%$ at 2023 \\
Russian Federation & & $4,5 \%$ at 2020 \\
\hline
\end{tabular}

As an explanation of rather meager plans of developed countries, let us draw your attention to the situation with RES development in Germany. Currently, increments and taxes upon "green" generation are mostly paid by population and small business. According to Bundesverband der Energie- und Wasserwirtschaft e.V. (BDEW) [6], in Germany, the difference in the price of energy by various types of consumers is highly significant:

- $\quad$ Starting from 29.42 eurocents $/ \mathrm{kW} \cdot \mathrm{h}$ - for households.

- Starting from 4,0 eurocents $/ \mathrm{kW} \cdot \mathrm{h}$ - for the industrial enterprises which are specifically important for country's economy.

Shrewd Germans have logically come to a conclusion, that so far as it is population that needs "green" generation, let them pay for it; whereas, in order to support competitiveness of German products the manufacturers must be provided with any governmental support ever.

A similar situation has occurred in most European countries (table 3).

Table 3. RES share and its price for population in some countries.

\begin{tabular}{lcc}
\hline Country & $\begin{array}{c}\text { RES share in the total volume of } \\
\text { generated power, } \%^{*}\end{array}$ & $\begin{array}{c}\text { Price of energy for households, } \\
\text { Russian Rubles per kW·h } * *\end{array}$ \\
\hline Denmark & 46,8 & 19,8 \\
Germany & 21,8 & 19,1 \\
Belgium & 11,5 & 17,6 \\
Portugal & 21,5 & 15,2 \\
Italy & 17,6 & 15,0 \\
Ireland & 25,0 & 15,0 \\
Spain & 23,4 & 14,7 \\
Russia & 0,1 & 3,1 \\
\hline
\end{tabular}

* Source - IEA

** Source - RIA rating

Further development of RES will largely be defined by perspectives of continued governmental financial support to this sector.

Also, it is worth mentioning that according to forecasts, the further increase in energy generation with the use of RES technologies will not have such "explosive" nature any more, which we witnessed lately [7] (figure 8). This for another time evidences the fact, that conventional ways of power generation will play a crucial role in energy generating industry for developed countries a long way down the road.

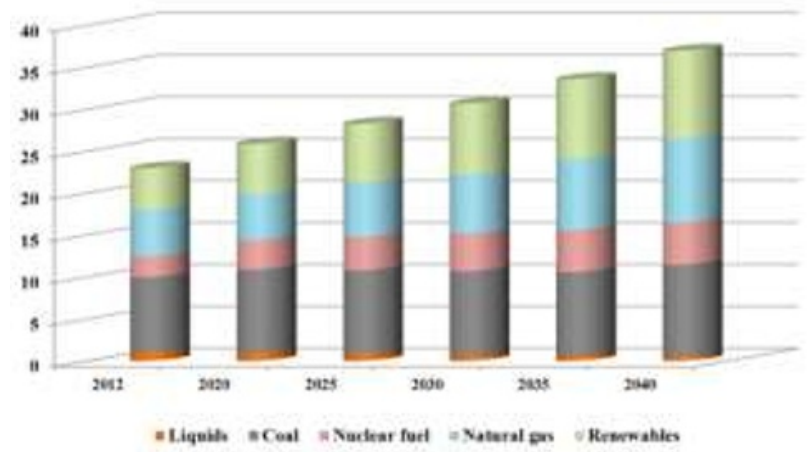

Fig. 8. Forecasted energy generation worldwide, by types of fuel, trillions of $\mathrm{kW}^{*} \mathrm{~h}$ 
RES-based electric utility industry in Russia. Matching with global trends.

Russia enters five leading countries in terms of energy generation. Electric energy complex OAO Unified Energy System of Russia (OAO RAO UES) comprises around 700 power plants with generating capacity exceeding 5 MW. As of early 2017, the total established capacity of OAO RAO UES power plants constituted $236.34 \mathrm{GW}$, and in 2017 г. it increased by $3.5 \mathrm{GW}$ (table 4), (source: AO SO UES) [8, 9].

Table 4. Structure of commissioned capacity of UES of Russia power plants.

\begin{tabular}{|c|c|c|c|c|c|c|c|c|c|c|c|}
\hline \multirow[t]{2}{*}{ Date } & \multirow{2}{*}{$\begin{array}{l}\text { Totally, } \\
\text { MW }\end{array}$} & \multicolumn{2}{|c|}{ TPP } & \multicolumn{2}{|c|}{ HPP } & \multicolumn{2}{|c|}{ WPP } & \multicolumn{2}{|c|}{ SPP } & \multicolumn{2}{|c|}{ NPP } \\
\hline & & MW & $\%$ & MW & $\%$ & MW & $\%$ & MW & $\%$ & MW & $\%$ \\
\hline 01.01 .2017 & 236344 & 160242 & 67,80 & 48086 & 20,34 & 10,9 & 0,01 & 75,2 & 0,03 & 27929 & 11,82 \\
\hline 01.01 .2018 & 239812 & 162780 & 67,88 & 48450 & 20,20 & 134,4 & 0,06 & 534,2 & 0,22 & 27914 & 11,64 \\
\hline
\end{tabular}

Remark. WPP - wind power plants; SPP - solar power plants.

Russian economy is the most "gaseous" in the world, including that, gas is the main fuel for thermal power plants with which NPPs compete in the European part and HPP - in Siberia. Coal-fired power industry holds a far less share. For illustrative purposes, below are data on electric-power generation by types of fuel by some regions of the world [10] (figure 9).

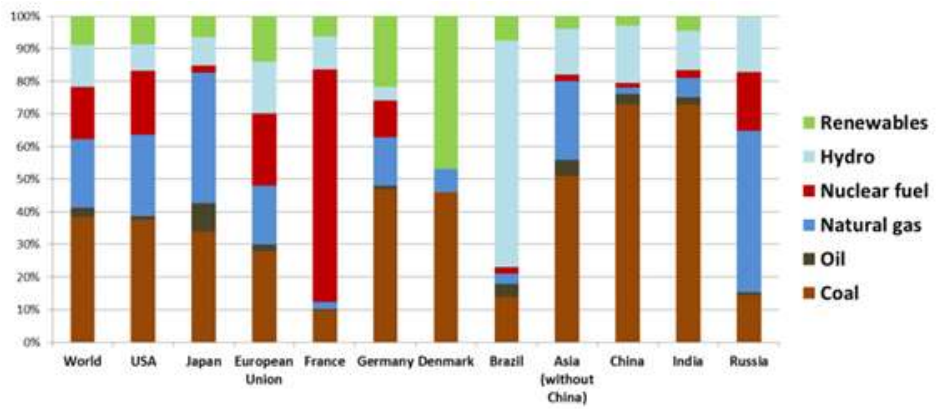

Fig. 9. Structure of electric power generation by fuel types, by countries and regions of the world

Due to such structure of fuel component, it can be stated that currently Russia has one of the best figures in the world in terms of specific values of $\mathrm{CO}_{2}$ emission at electric energy generation [11] (figure 10).

Apart of that, it is worth mentioning that our country is in the group of industrially developed countries with minimal volumes of $\mathrm{CO}_{2}$ emissions [12] (figure 11).

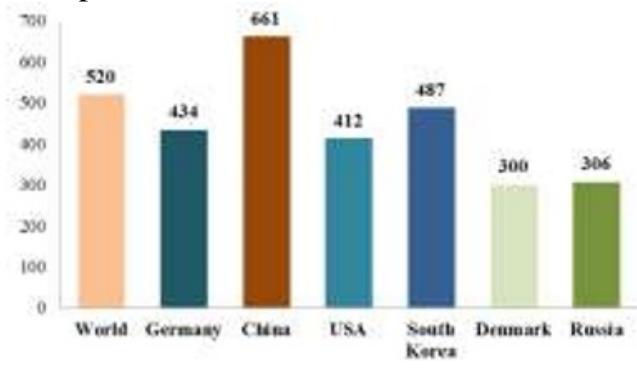

Fig. 10. Comparison of specific values of $\mathrm{CO}_{2}$ emissions for electric energy generation, $\mathrm{CO}_{2} / \mathrm{kW} * \mathrm{~h}$

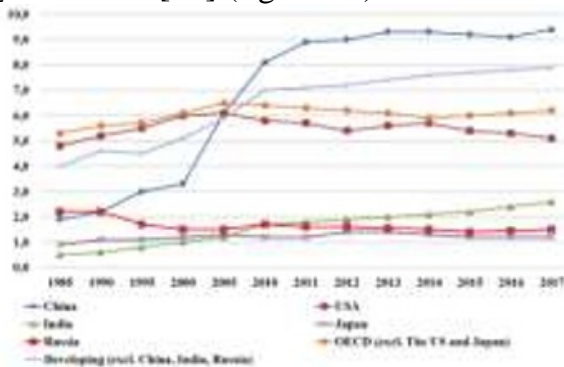

Fig. 11. Dynamics of $\mathrm{CO}_{2}$ emissions by leading countries and regions of the world, 1985-2016, bln.tons $\mathrm{CO}_{2}$ per year

According to forecasts of U.S. EIA, this situation tends to continue during some decades to come [7] (figure 12). 


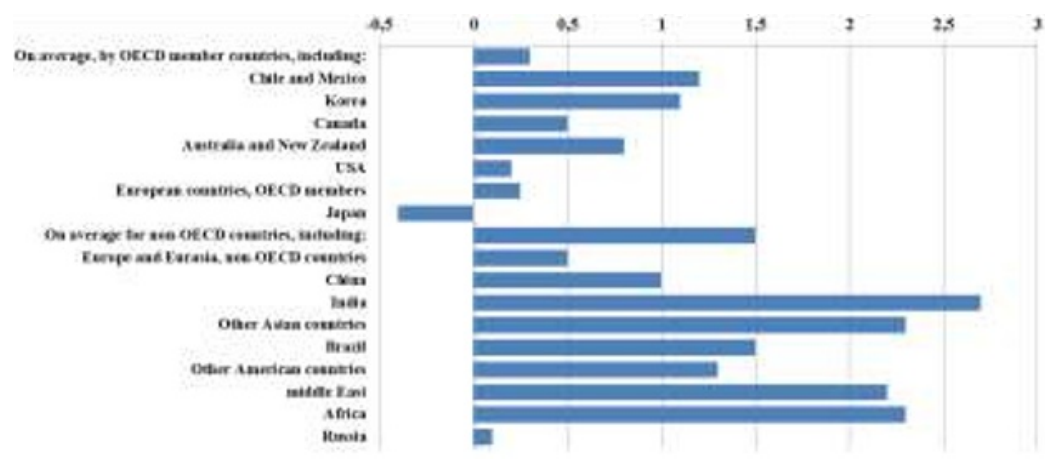

Fig. 12. Forecast of average annual growth of $\mathrm{CO}_{2}$ emission at electric energy generation in some countries for the period up to 2040, per cent per year

Technical potential of RES for Russia constitutes approximately $4.6 \mathrm{bln}$. tons of fuel equivalent (t.f.e.) per annum; which almost 4 times exceeds current level of Russia's power consumption, which constitutes around 1.2 bln. t.f.e. per annum [13, 14].

In 2017, renewable energy industry of Russia received a powerful driver for development: according to AO SO UES, electric energy generation by similar types of power plants multiply increased (table 5).

Table 5. Balance of electric energy generation by UES of Russia in 2016 and 2017.

\begin{tabular}{lccc}
\hline \multirow{2}{*}{ Index } & $\begin{array}{c}2016 \\
\text { million } \mathrm{kWh}\end{array}$ & million $\mathrm{kWh}$ & 2017 \\
& & & \\
$2017 / 2016, \%$ \\
\hline $\begin{array}{l}\text { Electric energy generation, totally } \\
\text { including: }\end{array}$ & & \\
TPP & 673676,2 & 671349,4 & 99,7 \\
HPP & 178306,1 & 178901,6 & 100,3 \\
WPP & 196397,8 & 202917,0 & 103,3 \\
SPP & 5,0 & 131,0 & 2620,0 \\
NPP & 71,7 & 563,0 & 785,2 \\
\hline
\end{tabular}

Whereas, it must be admitted that such considerable growth in relative terms is a consequence of a very low basis of estimate in the preceding year. Generally, volume of RES-based electric energy generation in Russia remains at a minimal level. Nevertheless, Russia will not stay aside of the global trend for development of stand-alone generation. This is reflected in "Forecast of research and engineering development of sectors of Russia's fuel and energy complex for the period up to 2035" [15], as prepared by the Ministry of energy of the Russian Federation in October 2016: “... unlikely, that Russia will stay aside of the global trend for development of stand-alone generation; and if Russian power plant industry is not ready for that, the market segment of RES in the country will turn out to be fully occupied by foreign manufacturers which work according to their standards".

Application of RES in isolated power-supply systems of Russia

Hereby, we suggest to consider in detail the "niches" which soon may be occupied with the help of using RES, i.e. to define where RES introduction is economically expedient and would successfully be developed having occupied a very substantial market share.

Russia possesses vast territories with extremely low population density, which are isolated from the centralised power-supply grid (figure 13). electric energy of isolated power-supply systems in minor communities is generated by diesel fuel power plants (further - DPP). The main problem is high cost of both fuel and its delivery costs. As a result, the economically feasible tariff for electric energy in the zone of decentralised power supply often exceeds $30 \mathrm{RR} / \mathrm{kW} \cdot \mathrm{h}[16]$. 


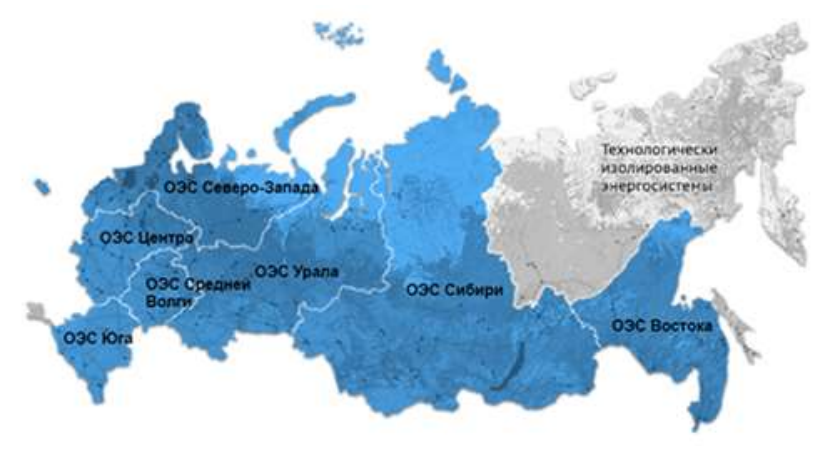

Fig. 13. Power-supply systems of Russia: UES - united power-supply system

Main problems in isolated power-supply systems:

- Small capacity of each separate power-supply system (50kWh - $12 \mathrm{MW}$ ).

- Worn-out equipment with high fuel consumption, whereas, a strict necessity for capacity reservation exists.

- Impossibility of technical modernisation connected with insufficiency of own sources which are formed by local power-generating industry.

- Fuel balance structure with a big specific weight of expensive diesel fuel (85\%). Higher-than-anticipated growth of diesel fuel price as compared to tariffs for electric energy.

- Seasonal character of fuel delivery, short navigational period, complicated logistics conditioned by underdeveloped transport infrastructure.

Whereas, potential capacity of solar and wind energy in those regions is highly significant.

Comparative analysis of a possibility to use SPP and WPP in such regions allows to make a conclusion about preferable use of SPP in northern conditions.

Obviously, SPP may not be the only power source in the isolated settlement. Moreover, the real share of energy from SPP in the total amount of energy consumed shall not exceed 20$25 \%$. However, even such partial substitution of DPP with SPP suggests considerable saving.

According to "RAO ES Vostoka" [17] in the decentralised sector of power supply in the Far East Federal District (FEFD) there are around 500 DPPs with the total capacity of 670 MW. Whereas, due to equipment wear the average level of consumption of fuel equivalent by those DPPs sometimes exceeds 500 gr of fuel equivalent $/ \mathrm{kW} \cdot \mathrm{h}$. Plus, huge shipping costs for delivery of expensive fuel for DPP.

Financial feasibility study for RES implementation project

Accepting the average capacity of one operating DPP as 1.3 MW. As an additional electricenergy source, an SPP with capacity around $300 \mathrm{~kW}$ is installed. The price for construction of a solar power plant "on a turn-key basis" is estimated approximately at USD 2 thous. for $1 \mathrm{~kW}$. Therefore, the total costs for facility commissioning may amount to around RR 42 $\mathrm{mln}$. This amount for the budget of a small community comprising several thousands or even hundreds of residents, is huge.

A real way-out in this situation may be involvement of a private investor to fund construction of SPP with subsequent repurchase of the finished object in installments. In order to avoid increase of financial burden over the local budget or population, the amount of the annual payment to the investor must comply with the price of saved diesel fuel (figure 14, figure 15). 


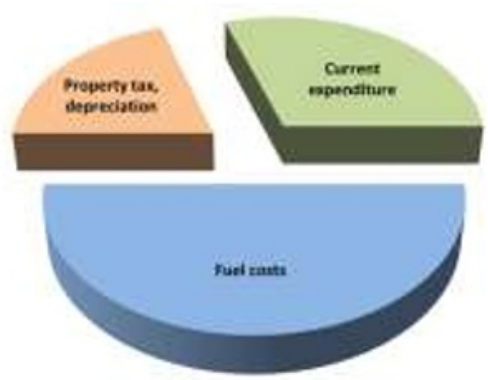

Fig. 14. Detailed structure of costs per DPP

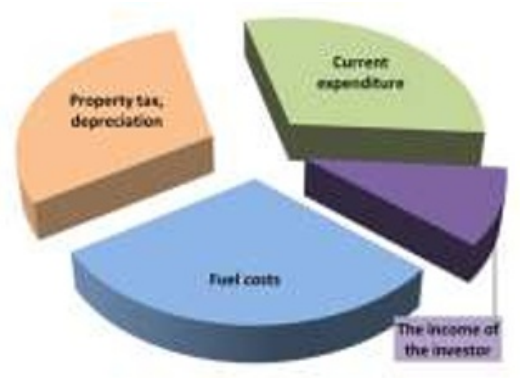

Fig. 15. Detailed structure of costs per SPP and DPP

By results of SPP introduction into local power-supply system, the share of fuel component in costs will be cut, property tax and depreciation for the account of commissioning of a new object shall be increased. Current costs will remain at the same level.

Make cost-effectiveness analysis of project implementation for the investor.

At installed capacity utilization factor (ICUF) of SPP equal to $19 \%$ obtain annual power generation around 500,000 $\mathrm{kWh}$. The annual saving of diesel fuel will result in 172.4 tons, subject to its price including shipping and storage costs of RR 70 thous. per ton it will result in saving of around RR $12 \mathrm{mln}$. per annum. Payments in the amount of this saving, subject to the forecasted inflation rate, shall be received by the investor for a period of six years. During this period the investor will operate SPP at its account, paying out all the current costs and taxes.

Results of project performance analysis are suggested in tables 6 and 7.

Table 6. Analysis of project economics as to substitution of a part of DPP with SPP

\begin{tabular}{|c|c|c|c|c|c|c|c|}
\hline Year & 2019 & 2020 & 2021 & 2022 & 2023 & 2024 & 2025 \\
\hline Period of operation, years & 0 & 1 & 2 & 3 & 4 & 5 & 6 \\
\hline Inflation rate & 1,054 & 1,054 & 1,037 & 1,037 & 1,037 & 1,037 & 1,037 \\
\hline $\begin{array}{l}\text { Payments to investor, subject to } \\
\text { inflation rate, thous. RR }\end{array}$ & & 12703 & 13173 & 13661 & 14166 & 14690 & 15234 \\
\hline Depreciation, thous. RR & & -2800 & -2800 & -2800 & -2800 & -2800 & -2800 \\
\hline Property tax, thous. RR & & -840 & -840 & -840 & -840 & -840 & -840 \\
\hline Operating expenses, thous. RR & & -630 & -665 & -698 & -729 & -758 & -789 \\
\hline Earnings before tax, thous. RR & & 8433 & 8869 & 9323 & 9797 & 10292 & 10805 \\
\hline Net gain, thous. RR & & 6747 & 7095 & 7458 & 7838 & 8234 & 8644 \\
\hline Money flow & -42000 & 9547 & 9895 & 10258 & 10638 & 11034 & 11444 \\
\hline $\begin{array}{l}\text { Money flow (cumulative) } \\
\text { thous. RR }\end{array}$ & -42000 & -32453 & -22558 & -12300 & -1662 & 9371 & 20815 \\
\hline $\begin{array}{l}\text { Discounted money flow } \\
\text { (discount rate } 12 \% \text { ), thous. RR }\end{array}$ & -42000 & 10030 & 9302 & 8629 & 8006 & 7429 & 6893 \\
\hline $\begin{array}{l}\text { Discounted money flow (cumulative) } \\
\text { thous. RR }\end{array}$ & -42000 & -31970 & -22668 & -14039 & -6033 & 1395 & 8288 \\
\hline
\end{tabular}

\begin{tabular}{lc}
\hline \multicolumn{2}{c}{ Table 7. Main indices of project on substitution of a part of DPP with SPP } \\
\hline Index & Value \\
\hline Cumulative pretax money flow for the complete project period, thous. RR & 32319 \\
Reduced money flow (NPV) & 8288 \\
Internal rate of return, before tax (IRR) & $18,5 \%$ \\
Simple pay-back period, years & 4,6 \\
Discounted pay-back period, years & 5,8 \\
\hline
\end{tabular}

In 6 years the investor transfers ownership of SPP to DPP owner. 
Provided estimates demonstrate that this project will have real economic effectiveness for the investor. Subject to the fact that average SPP operating period constitutes 20-25 years, this project is also very beneficial for the new owner.

Further, we will provide another simple estimate which demonstrates another peculiarity, which must be taken into account at construction of RES-based power plants. For an isolated settlement this is not actual, but for major cities in highly populated areas, this may be highly critical.

In southern California (USA) in November, 2014, a then the most powerful photovoltaic power plant named Topaz Solar Farm with the total installed capacity of $550 \mathrm{MW}$, was commissioned. The total area of the farm constitutes 9.5 sq. miles (25.6 sq.km). According to U.S. EIA in 2017 the farm generated 1.25 billion $\mathrm{kW} \cdot \mathrm{h}$ of electric energy (ICUF around $27 \%$ ).

"MosEnergo" PAO during the same period generated 57.86 billion $\mathrm{kW} \cdot \mathrm{h}$ of electric energy (ICUF - around $51.2 \%$. It is easy to calculate that in order to generate the same amount of energy, over 45 farms like Topaz Solar Farm would be required. Their total area would constitute 1,175 sq. km. For reference: the area of Moscow city before 2011 extension amounted to a little more than 1,100 sq.km.

Thus, in order to generate the amount of energy comparable with that generated by "MosEnergo", SPP with the area exceeding that of Moscow city within the Moscow Ring Road (MKAD) would be required.

\section{Conclusion}

Implementation of "Smart city" concept in our country is possible not only within the frames of complex introduction of a majority of its components in major cities, but also as application of separate elements in small communities, which is clearly demonstrated by development of RES in Russia in isolated power-supply systems, where similar projects are substantiated both socially and economically.

\section{References}

1. https://www.iea.org/wei2018/ World Energy Investment 2018, International Energy Agency. 251p.

2. Shilkina S. V. Economy of electric power industry development on renewable energy sources in Russia taking into account the world tendencies. Vestnik grazhdanskikh inzhenerov - Bulletin of Civil Engineers, 2018, no. 3 (68), pp. 137- 146.

3. http://www.greengrowthknowledge.org/sites/default/files/downloads/resource/Global Trends in Renewable Energy_Investment_Report_2018.pdf Global Trends in Renewable Energy Investment 2018, Frankfurt School-UNEP Centre/BNEF. 86p.

4. http://www.iea.org/publications/freepublications/publication/world-energy-investment2016.html World Energy Investment 2016. International Energy Agency.177 p.

5. http://www.ren21.net/wp-content/uploads/2018/06/178652_GSR2018_FullReport web_final_pdf Renewables 2018 global status report. International non-profit association REN21. 325p.

6. https://www.bdew.de/service/anwendungshilfen/erneuerbare-energien-und-das-eegzahlen-fakten-grafiken-2017/ Fakten und Argumente Erneuerbare Energien und das EEG: Zahlen, Fakten, Grafiken (2017). BDEW Bundesverband der Energie- und Wasserwirtschaft e.V., 45p.

7. https://www.eia.gov/outlooks/ieo/pdf/0484\%282016\%29.pdf International Energy Outlook 2016. U.S. Energy Information Administration. 290p. 
8. https://so-ups.ru/fileadmin/files/company/reports/disclosure/2017/ups_rep2016.pdf Report on functioning of Russia's united power-supply system in 2016. "System operator of United power-supply system" (AO "SO UES"). 39 p.

9. http://so-ups.ru/fileadmin/files/company/reports/disclosure/2018/ups rep2017.pdf Report on functioning of Russia's united power-supply system in 2017. "System operator of United power-supply system" (AO "SO UES"). 37 p.

10. http://ac.gov.ru/files/publication/a/7945.pdf Bulletin of social-economic crisis in Russia: Dynamics of electric energy consumption as economic activity indicator. Analytical centre with the Government of the Russian Federation. 2016. 20 p.

11. Beloborodov S.S. Reduction in $\mathrm{CO}_{2}$ emission: development of co-generation or construction of RES? // EnergoSovet. Jan. 2018. № 1 (51), URL: http://www.energosovet.ru/bul_stat.php?idd=687

12. http://ac.gov.ru/files/publication/a/15600.pdf Edited by S.N. Bobylev, L.M. Grigorieva. Report on human development in the Russian Federation for 2017. Environment priorities for Russia. M.: Analytical centre with the Government of the Russian Federation. 2017. 292 p.

13. State report "On state and protection of the environment of the Russian Federation in the year 2015". - M.: Ministry of Natural Resources and Environment of Russia; NIAPriroda

14. State report "On state and protection of the environment of the Russian Federation in the year 2016". - M.: Ministry of Natural Resources and Environment of Russia; NIAPriroda

15. Ministry of power of the Russian Federation "Forecast of research and engineering development of sectors of Russia's fuel and energy complex for the period up to 2035" M. 2016. 106 c. https://minenergo.gov.ru/node/6365

16. Marinychev P.A. Perspective of development of electric utility industry and renewable energy sources (RES) in the Republic of Sakha (Yakutiya) // Report by Marinychev P.A., Deputy Chairman of the Government of the Republic of Sakha (Yakutiya), delivered at the third conference "Development of renewable energy generating industry in the Far East of Russia", Yakutsk, June 2014.

17. Kaplun A.A. Perspectives for RES project development in decentralised regions of DFO // Report by Kaplun A.A., Deputy Director General on strategy and investments of OAO "RAO ES Vostoka" at the second conference "Development of renewable energy generating industry in the Far East of Russia", Yakutsk, June 2013. 